\title{
Irrigation induced surface cooling in the context of modern and increased greenhouse gas forcing
}

\author{
Benjamin I. Cook $\cdot$ Michael J. Puma \\ Nir Y. Krakauer
}

Received: 28 June 2010/ Accepted: 14 October 2010

(C) Springer-Verlag (outside the USA) 2010

\begin{abstract}
There is evidence that expected warming trends from increased greenhouse gas (GHG) forcing have been locally 'masked' by irrigation induced cooling, and it is uncertain how the magnitude of this irrigation masking effect will change in the future. Using an irrigation dataset integrated into a global general circulation model, we investigate the equilibrium magnitude of irrigation induced cooling under modern (Year 2000) and increased (A1B Scenario, Year 2050) GHG forcing, using modern irrigation rates in both scenarios. For the modern scenario, the cooling is largest over North America, India, the Middle East, and East Asia. Under increased GHG forcing, this cooling effect largely disappears over North America, remains relatively unchanged over India, and intensifies over parts of China and the Middle East. For North America, irrigation significantly increases precipitation under modern GHG forcing; this precipitation enhancement largely disappears under A1B forcing, reducing total latent heat fluxes and the overall irrigation cooling effect. Over India, irrigation rates are high enough to keep pace with increased evaporative demand from the increased GHG forcing and the magnitude of the cooling is maintained. Over China, GHG forcing reduces precipitation and shifts the region to a drier evaporative regime, leading to a relatively increased impact of additional water from irrigation on the surface energy balance. Irrigation enhances
\end{abstract}

B. I. Cook $(\bowtie) \cdot$ M. J. Puma

NASA Goddard Institute for Space Studies,

2880 Broadway, New York, NY 10025, USA

e-mail: bc9z@ldeo.columbia.edu

N. Y. Krakauer

City College of New York, 160 Convent Avenue,

New York, NY 10031, USA precipitation in the Middle East under increased GHG forcing, increasing total latent heat fluxes and enhancing the irrigation cooling effect. Ultimately, the extent to which irrigation will continue to compensate for the warming from increased GHG forcing will primarily depend on changes in the background evaporative regime, secondary irrigation effects (e.g. clouds, precipitation), and the ability of societies to maintain (or increase) current irrigation rates.

\section{Introduction}

Recent trends in global climate are dominated by the influence of increased atmospheric greenhouse gas (GHG) concentrations (Solomon et al. 2007). At the regional and local scale, however, land surface change remains a first order climate forcing with localized impacts that can be orders of magnitude larger than the signal from globally well mixed GHG (Pielke Sr et al. 2002). Roughly $40 \%$ of the global land surface area has been directly modified by human activities, primarily through conversion of natural ecosystems to croplands and pastures (Foley et al. 2005). These land cover changes affect climate by altering the balance and partitioning of energy at the surface and modulating the transfer of energy and mass fluxes between the surface and the atmosphere. Climate system responses to anthropogenic land cover changes have been widely investigated for a variety of time periods and climate scenarios (e.g. Feddema et al. 2005; Pongratz et al. 2010). Recent studies have also begun considering the influence of changes in land cover intensity and quality (e.g. Lobell et al. 2006b; Oleson et al. 2008; Oleson et al. 2010), including irrigation (Boucher et al. 2004; Lobell et al. 2006a; Puma and Cook 2010; Sacks et al. 2009). 
About $2 \%$ of the global land area is irrigated $(17 \%$ of cultivated area) (Bonfils and Lobell 2007; FAO 2002). Irrigation affects the surface energy balance by increasing the supply of moisture available for evapotranspiration (ET). In cases where ET is limited by moisture availability (instead of incoming energy), the addition of water to the surface via irrigation increases ET and shifts the surface energy balance to increasingly favor latent over sensible heating, reducing the Bowen ratio. This shift in surface energy partitioning is usually accompanied by a decrease in soil and near surface air temperatures, typically affecting the diurnal maximum more than the minimum (Lobell and Bonfils 2008; Sacks et al. 2009). This localized first order impact of irrigation on surface temperature is fairly robust, and has been documented extensively in both modeling (Adegoke et al. 2003; Sacks et al. 2009) and observational (Bonfils et al. 2008; Lobell and Bonfils 2008) studies. Second order effects of irrigation (i.e. changes in precipitation, cloudiness, water vapor, etc) are much more uncertain, but may extend over larger spatial scales (Boucher et al. 2004).

Recent studies suggest that, in some areas, irrigation induced cooling may be offsetting the warming that would be expected from increases in anthropogenic GHG (Bonfils and Lobell 2007; Kueppers et al. 2007; Lobell et al. 2008). Kueppers et al. (2007), for example, used a regional model to conclude that temperature trends in the Central Valley of California were due to the intensification of irrigation, and that this was masking the expected warming from GHG. In light of this, it is important to understand how much warming is being masked by irrigation, and whether this masking effect will maintain, increase, or diminish into the future.

We use an atmosphere general circulation model, coupled to a thermodynamic mixed layer ocean ('q-flux'), to investigate the magnitude of the irrigation cooling effect under modern and increased (SRES A1B) GHG scenarios (Nakicenovic et al. 2000). Instead of using empirical estimates of irrigation and GHG forcing of climate, as other studies have done (Bonfils and Lobell 2007; Lobell et al. 2008), we use a general circulation model with observation-based estimates of irrigation integrated directly into the model. In this way, irrigation and GHG impacts on surface temperature are physically modeled, allowing for interactions and feedbacks within the climate system that may amplify or dampen the effect of irrigation. This study extends previous work by Puma and Cook (2010), who integrated irrigation into transient climate simulations of the twentieth century. They demonstrated that irrigation impacts on climate (temperature and precipitation) were highly variable spatially and temporally over the course of the twentieth century, and that these patterns were driven by changes both in irrigation intensity and in the background climate. As we move into an era of unprecedented human forcing of climate with increased GHG forcing, and as questions of water resource sustainability become vital for many regions, it is important to understand how irrigation-climate interactions may continue to change.

\section{Data and methods}

\subsection{GISS ModelE}

All experiments were conducted using the Goddard Institute for Space Studies (GISS) atmosphere general circulation model ('ModelE') (Schmidt et al. 2006), run at $2^{\circ} \times 2.5^{\circ}$ horizontal resolution with 40 vertical layers. ModelE's simulation of modern day climate compares favorably with observations, with some notable biases, particularly in the subtropical marine stratocumulus regions. Hansen et al. (2007) found that the GISS ModelE faithfully replicates the climate of the twentienth century, including trends and low and high frequency variability, when forced with observed climate forcings and SSTs. The land surface is divided into vegetated and bare soil columns that extend to a maximum depth of $3.5 \mathrm{~m}$. Vegetation and phenology is prescribed (after Matthews 1983, 1984) and the model distinguishes among eight vegetation types for its photosynthesis and stomatal conductance calculations using the well-known functions of Farquhar et al. (1980) and Ball et al. (1987), respectively. More detailed discussions of GISS ModelE formulations and performance can be found in the available literature (Hansen et al. 2007; Rosenzweig and Abramopoulos 1997; Schmidt et al. 2006). In our experiments, we ran ModelE in 'q-flux' mode, with the ocean represented as a 65-m deep mixed layer. With this q-flux approximation, the model takes approximately 10 years to reach equilibrium when driven by constant forcings.

\subsection{Irrigation in ModelE}

Irrigation rates and locations are taken from a global gridded reconstruction of twentieth century hydrography (Wisser et al. 2010). In ModelE, irrigation water is added to the vegetated fraction of the grid cell at the top of the soil column, beneath the vegetation canopy. Water for irrigation is initially withdrawn from surface water reservoirs (rivers and lakes) in the same grid cell. If irrigation demand is not satisfied by these surface sources, additional water is added from outside the system, with the assumption that the water is coming from groundwater sources disconnected from the hydrologic cycle. For days with nonzero irrigation, this flux is kept constant over the course of 
the day and is applied for every sub-daily time step. The timing of irrigation water application in our model is highly idealized, but (we feel) reasonable given the paucity of data on specific irrigation timing and the likely high variability between regions in how irrigation is applied. We also note that a previous study (Sacks et al. 2009) conducted their own sensitivity analysis and found that modeled climate responses to irrigation were largely insensitive to the timing of irrigation. Once the irrigation water is applied, it either infiltrates the soil column or leaves the grid cell as surface runoff. Infiltrating irrigation water can then be removed from the soil column through evapotranspiration and underground runoff, such that that the model will have an irrigation efficiency that depends on our model's climate and land-surface properties.

Seasonal irrigation totals are shown in Fig. 1. Irrigation is most extensive in the Northern Hemisphere during boreal summer (June-July-August, JJA), with highest rates over China, India, the Middle East, and North America. In the Southern Hemisphere, irrigation is primarily localized over limited regions of Australia and South America, with highest rates during austral spring (September-OctoberNovember, SON) and summer (December-JanuaryFebruary, DJF). For more details on the integration of irrigation into ModelE, we refer interested readers to Puma and Cook (2010).

\subsection{Experimental setup}

We conducted four experiments: a modern control run with no irrigation and year 2000 GHG concentrations (MC, 'modern control'), a modern irrigation run with modern irrigation rates and year 2000 GHG concentrations (MI, 'modern irrigation'), a future control run with no irrigation and year 2050 GHG concentrations from the SRES A1B scenario (FC, 'future control'), and a future irrigation run with modern irrigation and year 2050 GHG concentrations from the SRES A1B scenario (FI, 'future irrigation'). Global irrigation totals and GHG concentrations for these scenarios are summarized in Table 1. Projections of irrigation rates into the future are highly uncertain and likely sensitive to a variety of physical, economic, and political constraints. There is some evidence that the recent expansion of irrigated areas may be beginning to plateau (Bonfils and Lobell 2007), and so we use modern irrigation rates in our FI scenario as a reasonable first choice, in light of the absence of other information.

Each simulation reached equilibrium conditions after 10 years of spin up. We ran each simulation for an additional 25 years, and based our subsequent analyses on these post spin up years. For our analyses, we focus on global land areas with the highest irrigation rates, where we expect the direct irrigation response to be strongest. Unless otherwise indicated, insignificant $(p>0.10)$ differences, as determined using a two sided Student's $t$ test, are masked out.

\section{Results}

\subsection{Controls on irrigation cooling}

To a large degree, the magnitude of cooling from irrigation in ModelE depends on (1) whether ET in a given grid cell
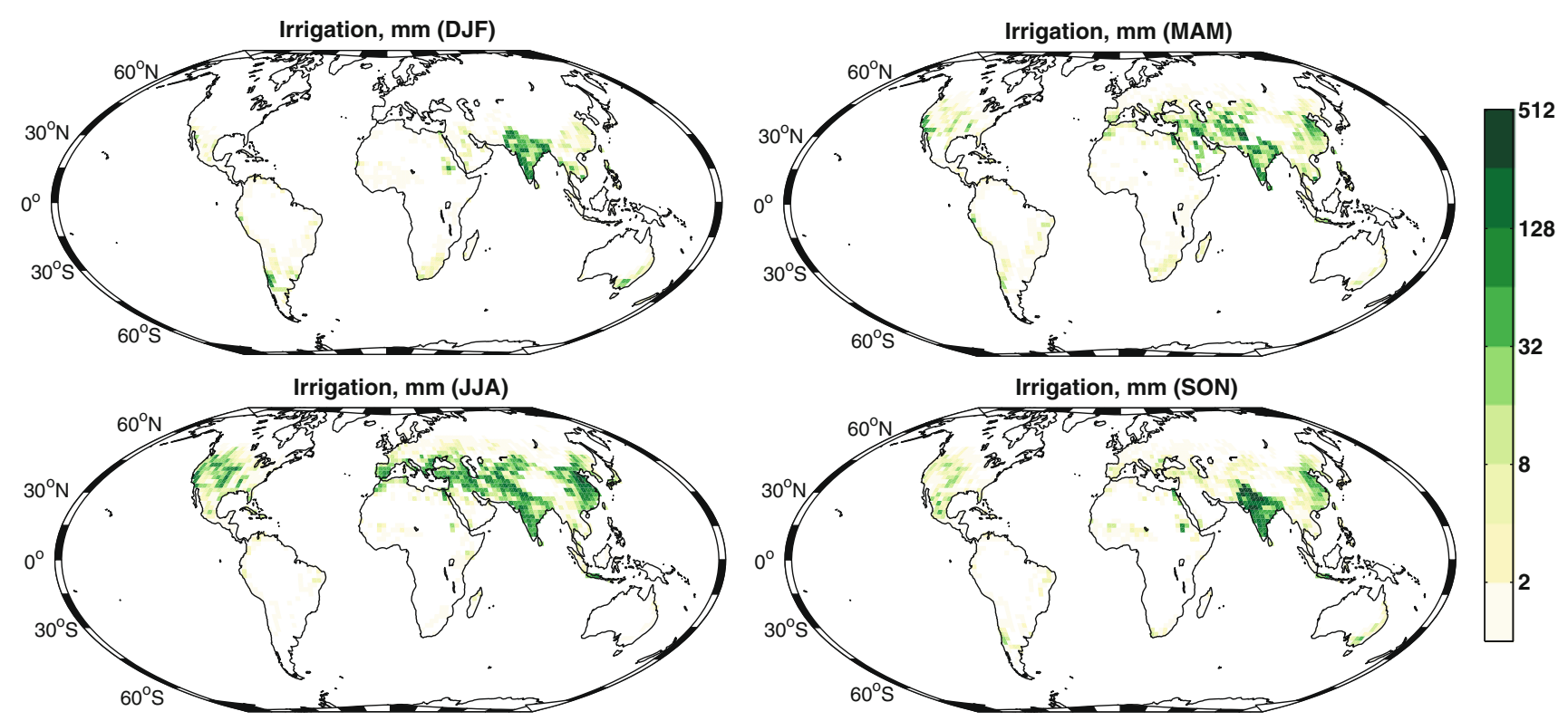

Fig. 1 Seasonal irrigation totals (mm). Scale is logarithmic 
Table 1 Boundary conditions for the GCM experiments. Irrigation amount is the global total, distributed as shown in Fig. 1

\begin{tabular}{lllll}
\hline Exp & $\begin{array}{l}\text { Irrigation } \\
\left(\mathrm{km}^{3} \text { year }^{-1}\right)\end{array}$ & $\mathrm{CO}_{2}(\mathrm{ppm})$ & $\mathrm{N}_{2} \mathrm{O}(\mathrm{ppb})$ & $\mathrm{CH}_{4}(\mathrm{ppb})$ \\
\hline MC & 0 & 369.6 & 316.3 & 1.752 \\
MI & 2931 & 369.6 & 316.3 & 1.752 \\
FC & 0 & 532.0 & 350.0 & 2.400 \\
FI & 2931 & 532.0 & 350.0 & 2.400 \\
\hline
\end{tabular}

is limited by moisture supply or incoming energy and (2) the irrigation rate. A good measure of whether ET is moisture or energy limited is evaporative fraction (EF), the ratio of latent to latent plus sensible heating. Low EF values (near zero) are indicative of arid and semi-arid regions, with high energy inputs and low available moisture. High EF values (near unity) are typical in humid regions with high moisture availability that can largely satisfy evaporative demand. Any increase in moisture availability, either from changes in climate or the addition of irrigation, will increase EF and shift the overall regime toward a more energy limited state. Figure 2 shows, for all irrigated grid cells, temperature responses to irrigation as a function of irrigation rate and EF for the modern case. The surface temperature anomaly (MI-MC) is on the $y$-axis, $x$-axis is the EF of the grid cells for the control (MC) case, and the colorbar indicates the irrigation rate $\left(\mathrm{mm} \mathrm{day}^{-1}\right)$. All rates and anomalies are grid cell averages. Higher irrigation rates generally lead to a larger irrigation cooling effect, with the magnitude of the anomalies modulated by the EF of the grid cell in the control (MC) simulation. Grid cells with a control case EF below about 0.2-0.4 generally show the largest temperature response to irrigation.

\subsection{Surface energy balance: irrigation and GHG forcing}

Increased GHG concentrations and irrigation both have the potential to alter the surface energy balance. Irrigation typically leads to increases in the net longwave flux at the surface through two complementary mechanisms modulated by increases in evapotranspiration (Fig. 3, top panel). First, the increased evapotranspiration cools the surface, reducing outgoing longwave fluxes. Second, this evaporated moisture increases near surface humidity, which in turn increases the flux of downwelling longwave radiation. The downwelling longwave radiation increases may spread over a large area beyond the core of the irrigated regions as this moisture is dispersed in the atmosphere. Irrigation has a small net negative effect on surface shortwave radiation in regions where irrigation increases cloud cover (Fig. 3, middle panel). In some regions (e.g. parts of Asia),
Irrig Cooling: MI-MC (ONDJFM)

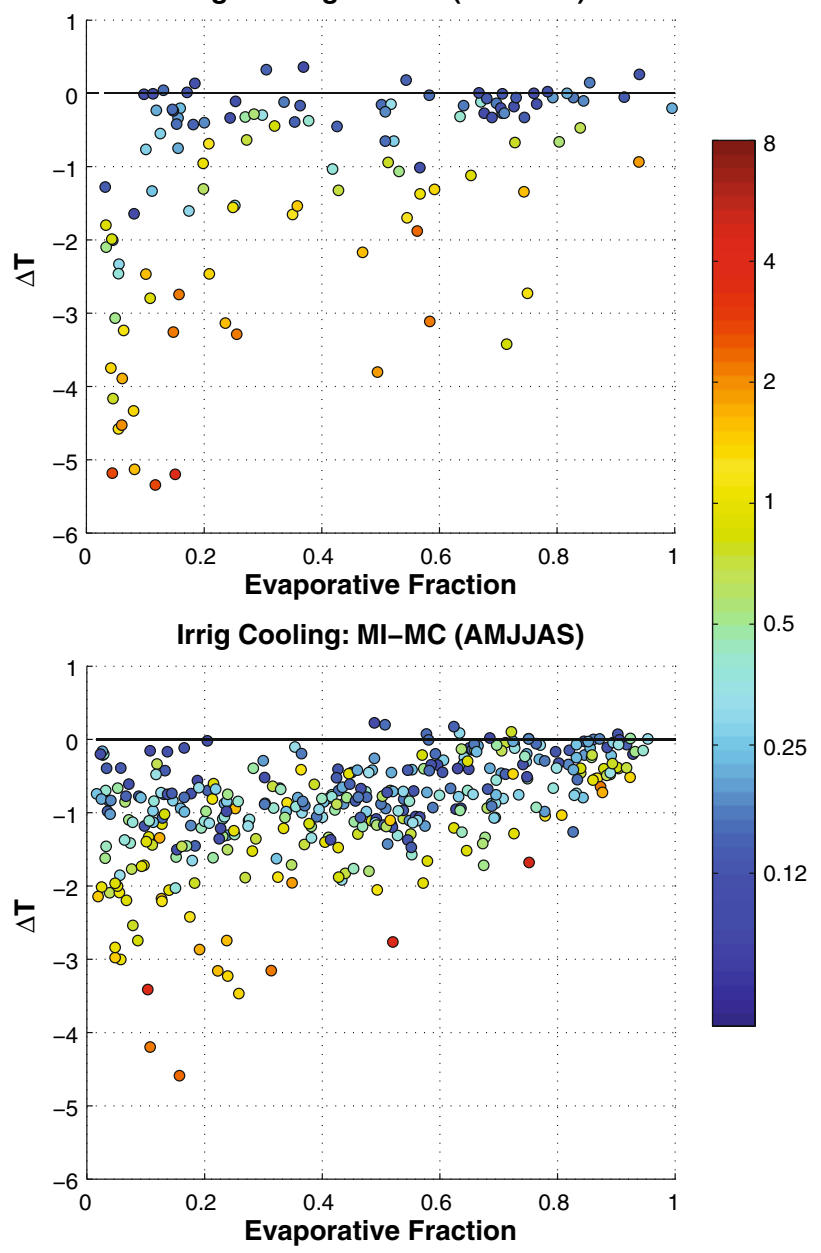

Fig. 2 Irrigation impacts on surface air temperature (MI-MC) (K) as a function of irrigation amount $\left(\mathrm{mm} \mathrm{day}{ }^{-1}\right.$, indicated by coloring) and evaporative fraction $(E F)$. The two seasons are October-March $(O N D J F M)$ and April-September (AMJJAS). Scale for the irrigation rate is logarithmic

irrigation in ModelE actually reduces cloud cover due to a weakening of the monsoon, leading to minor localized increases in surface shortwave radiation. Surface longwave increases generally overcompensate for decreases in shortwave, resulting in net increases in total net surface radiation (Fig. 3, bottom panel) localized over the major irrigated regions.

Increased GHG concentrations lead to globally widespread increases in surface longwave fluxes, primarily through increases in downwelling longwave radiation (Fig. 4, top panel). Some regions do show negative longwave anomalies at the surface (e.g. southern Africa, parts of Asia). These are areas where GHG warming leads to regional drying from reductions in precipitation and cloud cover, allowing more longwave to escape to space. In the global mean, however, GHG warming leads to increased evapotranspiration (especially from the oceans), precipitation, and 


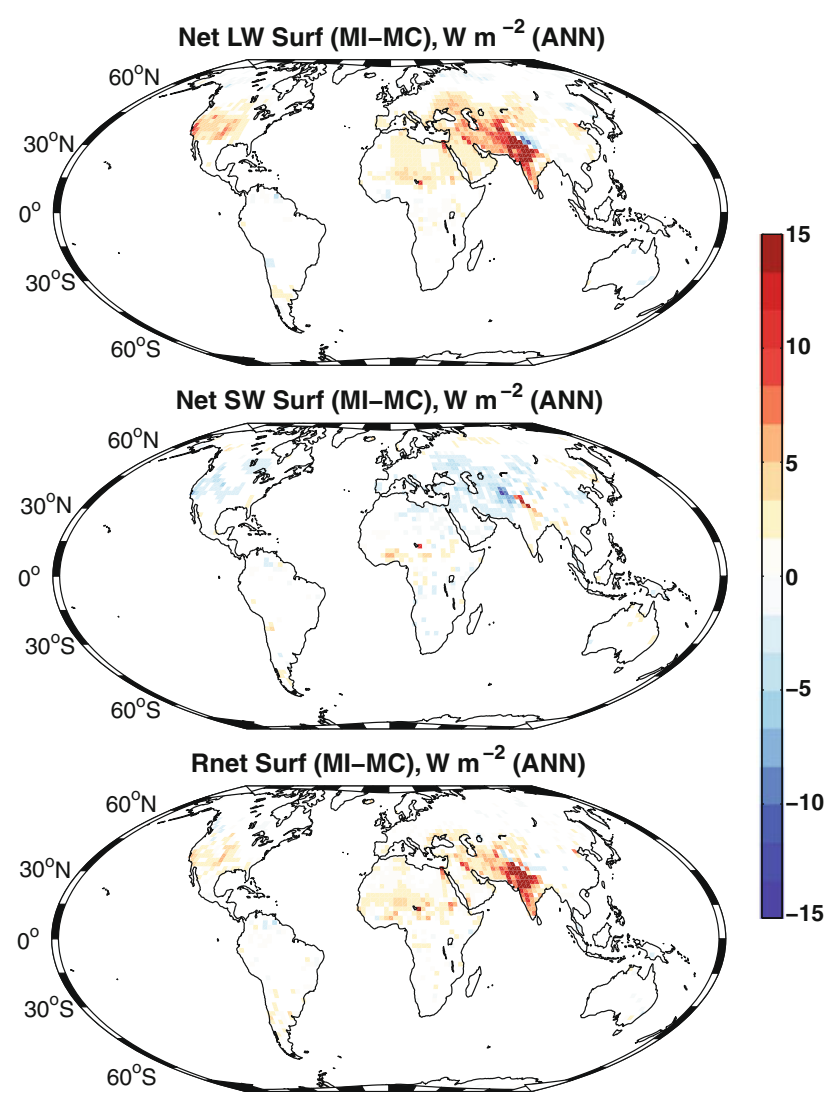

Fig. 3 Annual differences in net surface radiation (longwave, shortwave, total) $\left(\mathrm{W} \mathrm{m}^{-2}\right)$ over land areas for the modern irrigation comparison (MI-MC). In this and the subsequent maps, insignificant differences $(p<0.10)$ are masked out

cloud cover. Negative surface shortwave anomalies are widespread (Fig. 4, middle panel), except in those regions with reduced cloud cover. Overall, increased GHG forcing leads to globally widespread increases in net radiation at the surface (Fig. 4, bottom panels).

Irrigation and GHG increases can also directly or indirectly affect the energy partitioning at the surface (Fig. 5). Irrigation has the most direct impact, increasing surface moisture and favoring latent over sensible heating. GHG impacts on the surface fluxes are more indirect, driven primarily by the impact of the GHG warming on the hydrologic cycle, resulting in a reduction in sensible heating and increase in latent heating over large continental regions. Over areas where precipitation is reduced, latent heat fluxes and surface moisture are also reduced and the bulk of the energy at the surface goes into sensible heating. This shows that, despite the globally homogeneous nature of the GHG forcing, the impacts on the surface energy balance and partitioning can be highly variable across space. Combined with the spatially variable nature of the irrigation forcing, this opens up the possibility for a variety of potentially synergistic or antagonistic interactions between irrigation and GHG forcing.
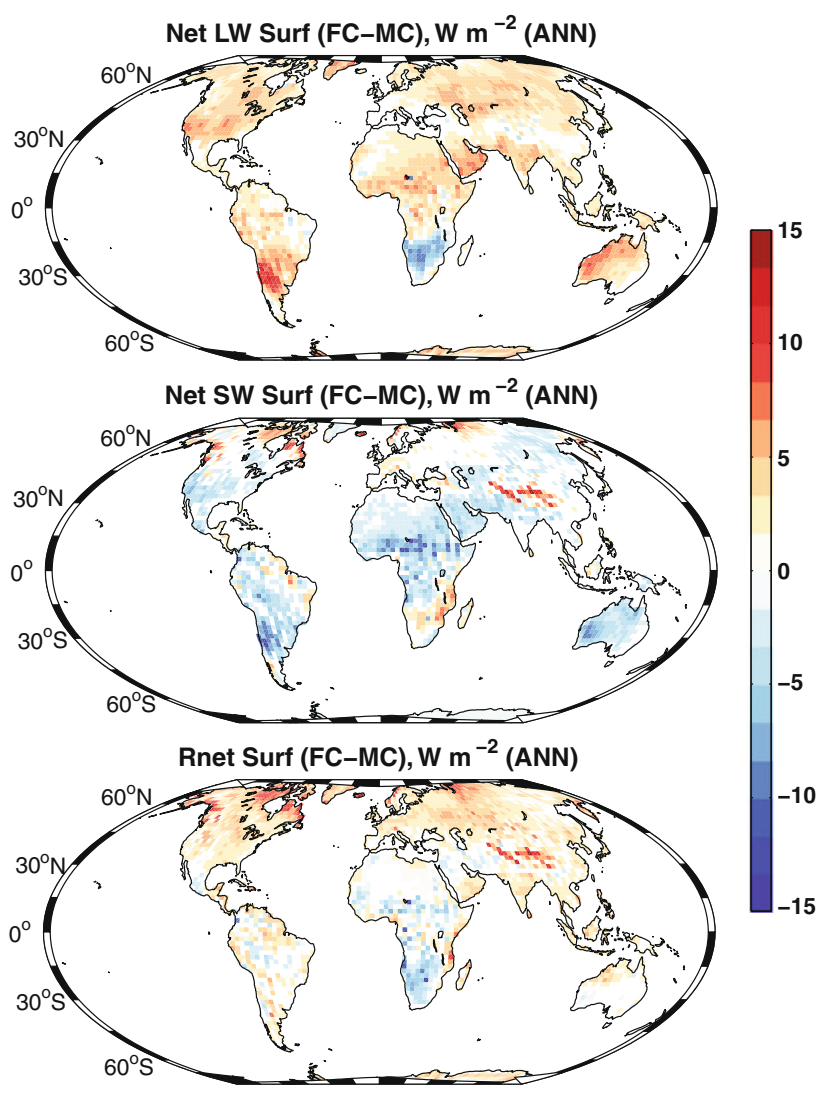

Fig. 4 Annual differences in net surface radiation (longwave, shortwave, total) $\left(\mathrm{W} \mathrm{m}^{-2}\right.$ ) over land areas due to $\mathrm{GHG}$ forcing as prescribed by the SRES A1B emission scenario (FC-MC)

\subsection{Irrigation effects: temperature and precipitation (MI-MC)}

The largest significant temperature responses generally map onto the regions with the highest irrigation rates (Fig. 6). Over India, there is significant cooling through all seasons, especially during the dry, off-monsoon seasons (DJF and SON) when the background EF is low and ET is moisture limited. The Mediterranean, Middle East, and North America show similar cool anomalies, primarily during boreal summer (JJA) when evaporative demand is highest. Despite high irrigation rates over China and Eastern Asia, there is only a relatively modest temperature response during JJA and SON. This region has a relatively high EF in the control case $(\geq 0.8)$, indicating ET is limited primarily by incoming energy, rather than moisture supply. There is also a large region of cooling in Eastern Europe/ Western Russia during March-April-May (MAM). Irrigation rates are negligible over this region during this season; the cooling arises from second order dynamical effects and is not a direct surface temperature response to irrigation.

Significant increases in precipitation (Fig. 7) generally occur downwind from the major irrigation areas in North 

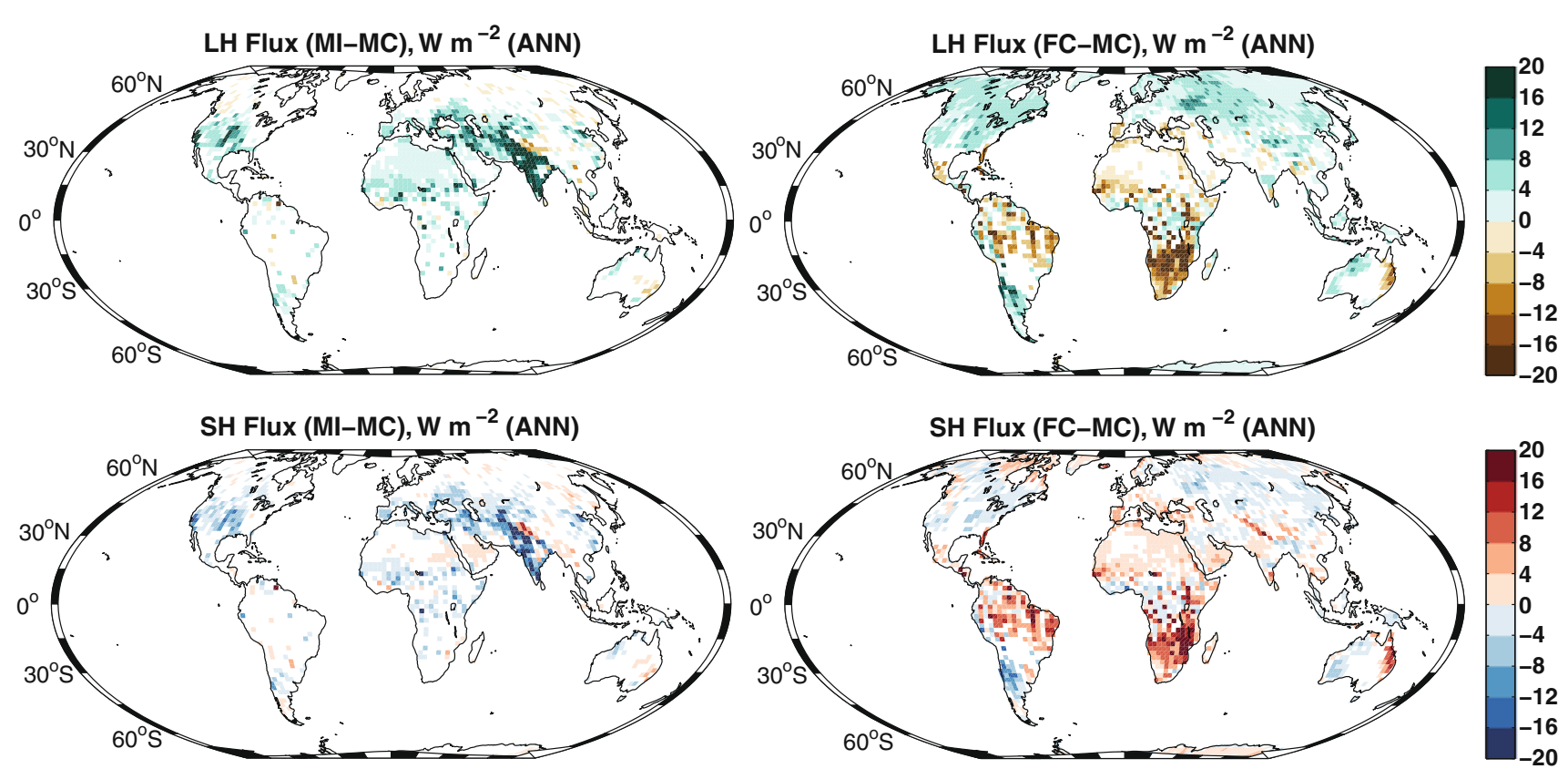

Fig. 5 Annual differences in surface latent $(L H)$ and sensible $(S H)$ heat fluxes $\left(\mathrm{W} \mathrm{m}^{-2}\right)$ over land areas. Left panels show differences for the the modern irrigation comparison (MI-MC) and right panels show

differences due to GHG forcing as prescribed by the SRES A1B emission scenario (FC-MC)
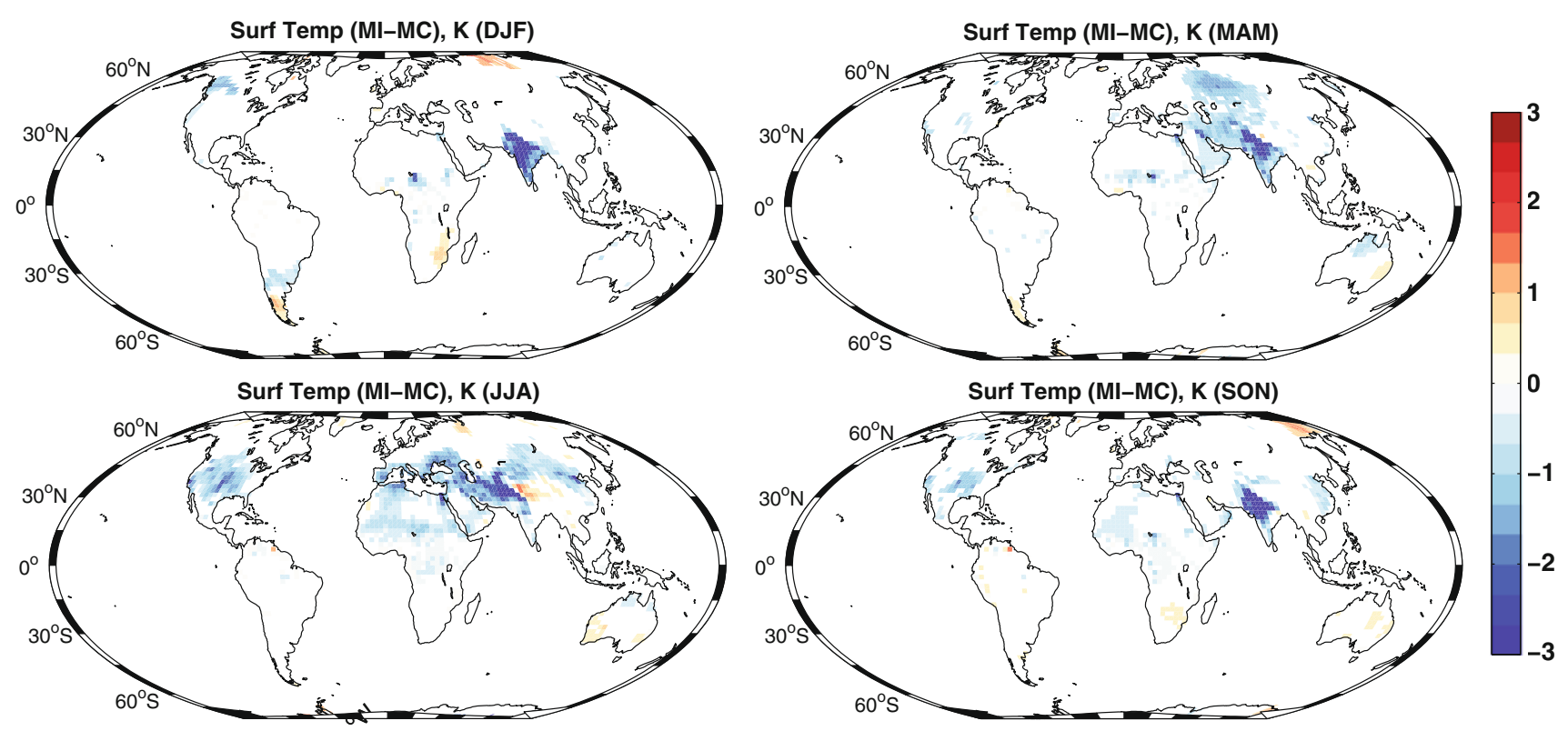

Fig. 6 Differences in surface air temperature (K) over land areas for the modern irrigation comparison (MI-MC)

America and Eurasia. Precipitation decreases over some regions of India and monsoon Asia, a result of cooler surface temperatures reducing the land-ocean temperature contrast and weakening the monsoon. There are some scattered precipitation increases over regions with fairly low irrigation rates (e.g. Africa), another result of second order dynamical responses in ModelE. As with other indirect response to the localized irrigation forcing (e.g. the
MAM cooling over Eastern Europe), the robustness of these results is highly uncertain.

\subsection{GHG effects: temperature and precipitation (FC-MC)}

Changes in the base climate, arising from increased GHG concentrations or other causes, could modulate the influence 

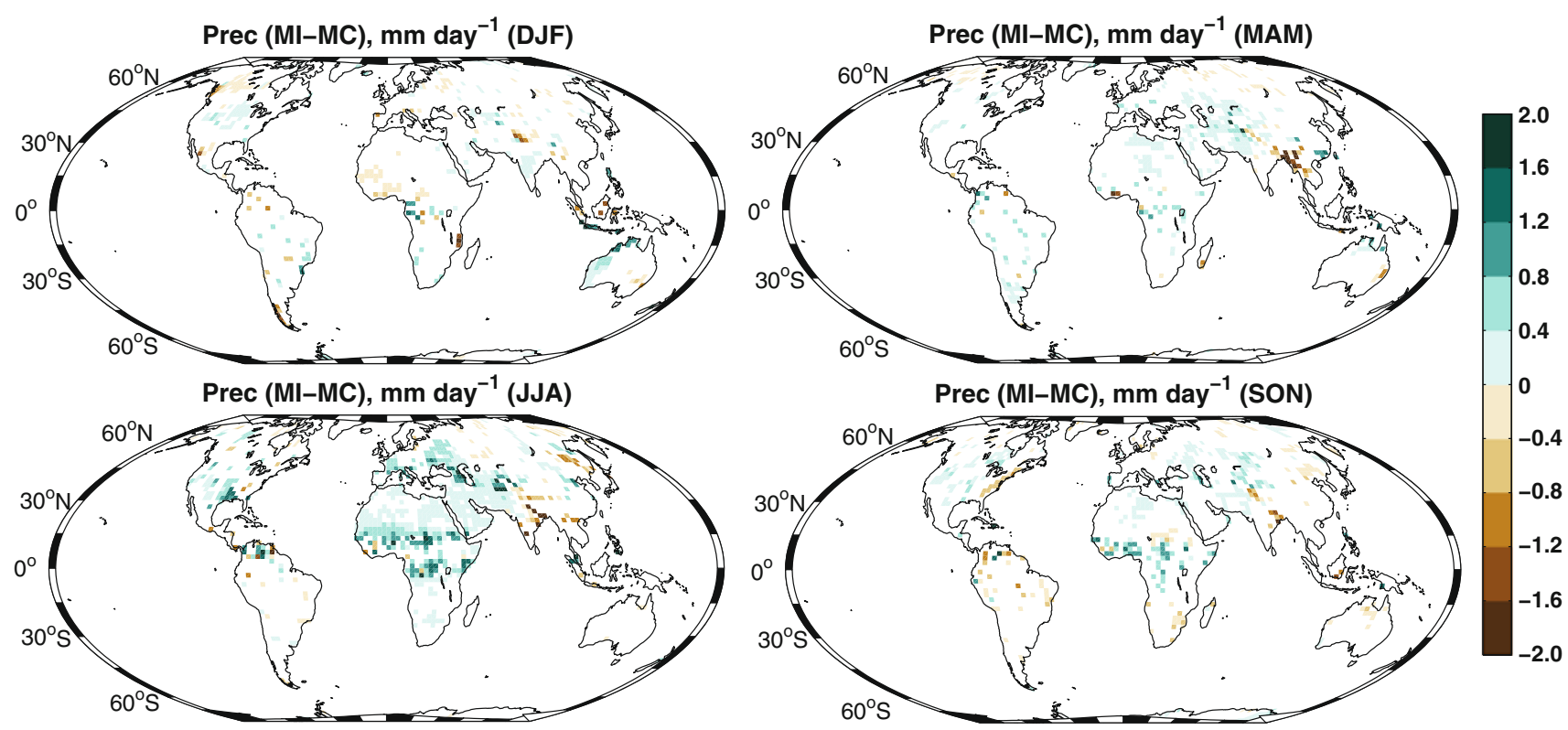

Fig. 7 Precipitation changes $\left(\mathrm{mm} \mathrm{day}^{-1}\right)$ over land areas for the modern irrigation comparison (MI-MC)

of irrigation on surface temperatures through a variety of mechanisms. If temperatures decrease or precipitation increases, shifting the base climate towards an energy limited evaporative regime, this would be expected to decrease the relative impact of irrigation on surface temperatures. Alternatively, increased temperatures or decreased precipitation would move the base climate towards a more moisture limited regime, increasing the relative impact of irrigation on surface temperatures. The ultimate shift in the baseline evaporative regime, and thus its impact on irrigation effects, also depend on the initial regime itself, and how far it is from transitioning between the moisture and energy limited cases. Also, GHG forced climate changes may modulate the magnitude of indirect irrigation effects on the climate system (e.g., clouds, precipitation), which could, in turn, modify the impact of irrigation on surface temperature.

Increased GHG forcing from the A1B scenario leads to significant warming over almost all land grid cells (Fig. 8), including all irrigated regions. Warming is generally largest in the high northern latitudes during boreal winter (DJF) and spring (MAM); averaged annually and over all land areas, the warming is $+2.3 \mathrm{~K}$ relative to modern GHG forcing. Precipitation responses are much more spatially variable, with general drying out in the tropics and subtropics and increased precipitation in the high and midlatitudes (Fig. 9). Precipitation increases over southern and eastern India, reflecting an enhanced summer (JJA) monsoon. Simultaneously, the monsoon weakens over China and Indochina, resulting in reduced precipitation over these regions. Precipitation increases over some parts of North America, although any changes over the irrigated center of the continent are weak or insignificant.

\subsection{Irrigation effects: future (FI-FC)}

Even under increased GHG forcing, irrigation still exerts a significant cooling effect over large regions (Fig. 10). The largest anomalies generally still coincide with the highest irrigation rates over India and the Middle East. To compare how the irrigation cooling effect has changed with increased GHG forcing, we can difference the irrigation induced anomalies between the increased and modern GHG runs (FI-FC minus MI-MC) (Fig. 11). In regions with positive (red) anomalies, the irrigation cooling effect is significantly diminished in the A1B GHG scenarios relative to modern; in regions with negative (blue) anomalies, the irrigation cooling effect is enhanced. Over much of North America, the irrigation influence is diminished, especially during JJA and SON. India remains relatively unchanged, while the irrigation effect appears to strengthen over parts of the Middle East, China, and Eastern Asia. The large area of dynamically induced cooling over Eastern Europe also largely disappears, although dynamical and remote responses to irrigation are often inconsistent across climate models (Puma and Cook 2010; Sacks et al. 2009), and we therefore take these to be less robust than the localized response in irrigated areas.

\subsection{Regional changes: North America}

For the modern case (MI-MC), associated irrigation effects on climate are largest during the late summer/early fall (Fig. 6), when irrigation rates are highest (Fig. 1) and the energy inputs are largest. Under increased GHG forcing, the magnitude of the irrigation cooling effect over NA 

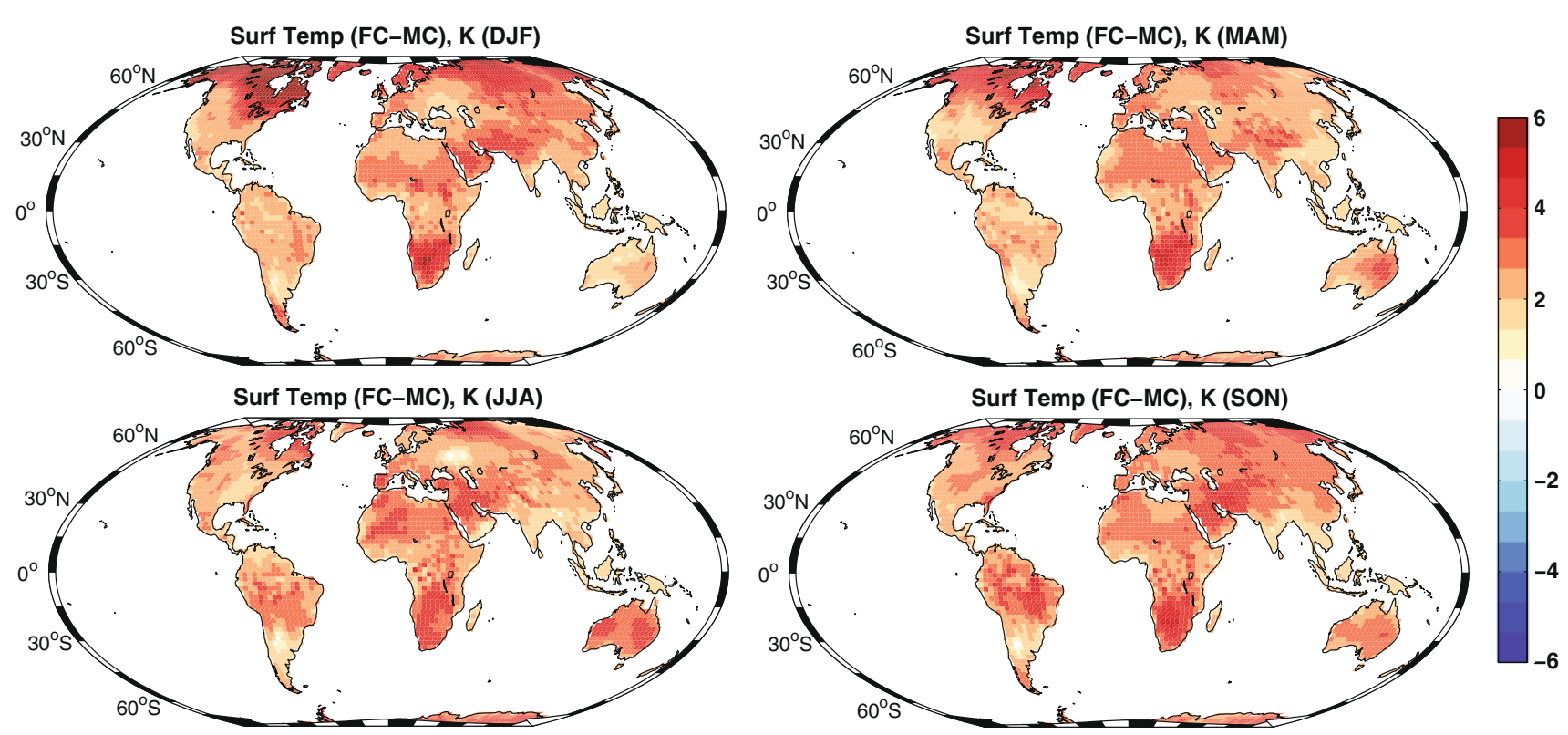

Fig. 8 Surface air temperature changes (K) over land areas due to GHG forcing as prescribed by the SRES A1B emission scenario (FC-MC)
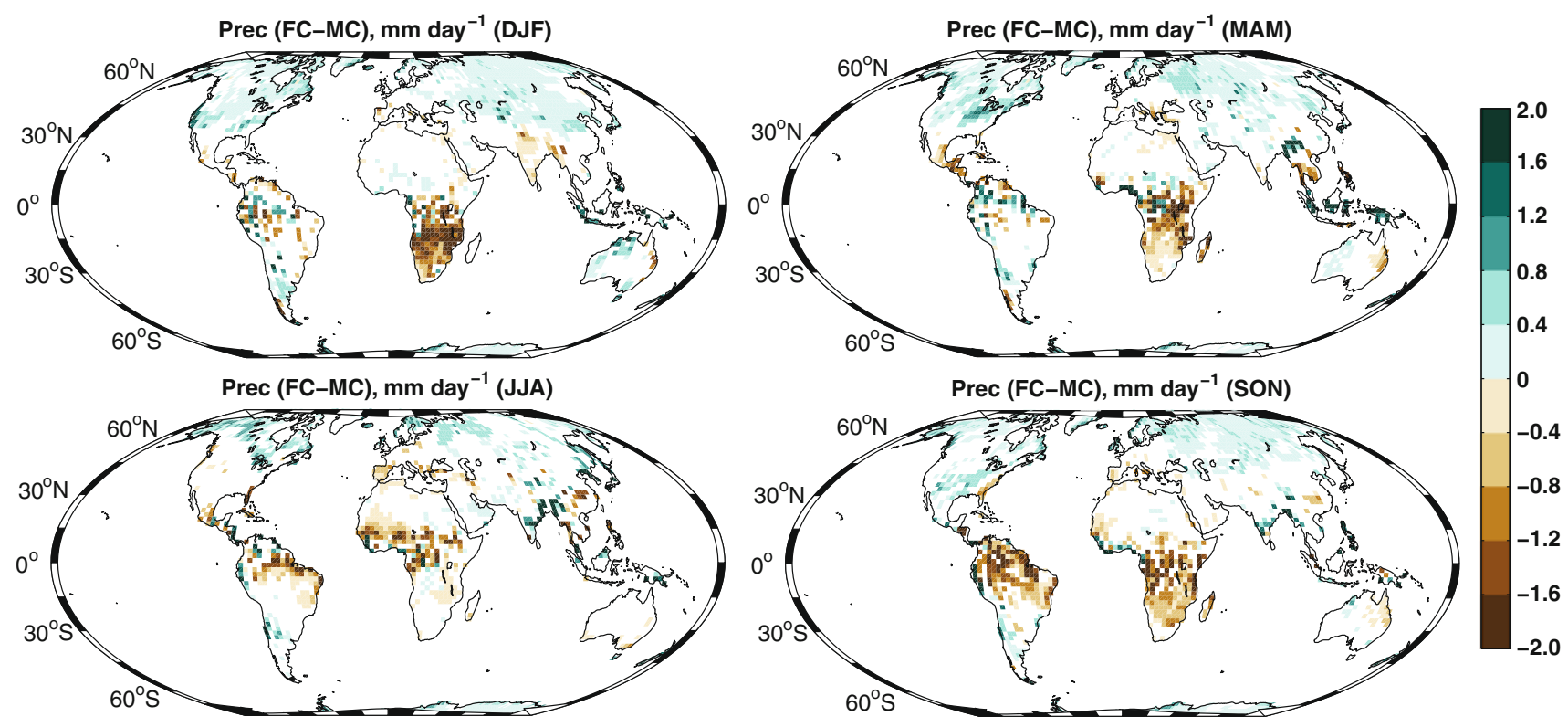

Fig. 9 Precipitation changes $\left(\mathrm{mm} \mathrm{day}^{-1}\right.$ ) over land areas due to GHG forcing as prescribed by the SRES A1B emission scenario (FC-MC)

decreases sharply, primarily during the late summer (JulyAugust) and autumn (October-November) (Fig. 12). Bulk LH flux anomalies are reduced throughout the year in the future comparison (FI-FC), relative to the modern (MI-MC) case. This comes from a reduction in irrigation mediated precipitation increases observed in the modern scenario. Irrigation during the summer season (JJA) over this area is $+0.30 \mathrm{~mm} \mathrm{day}^{-1}$; the precipitation enhancement over this same area from irrigation in the modern case is the same $\left(+0.30 \mathrm{~mm} \mathrm{day}^{-1}\right)$, effectively doubling the irrigation rate and associated latent heat fluxes. Contrast this to the future scenario, when the precipitation enhancement is an order of magnitude lower $\left(+0.05 \mathrm{~mm} \mathrm{day}^{-1}\right)$. Without the extra input of moisture from the precipitation response, irrigation in the A1B scenario has a diminished impact on surface LH fluxes and EF, reducing the total cooling effect.

\subsection{Regional changes: China}

Over China, increased GHG forcing leads to precipitation reductions over much of the irrigated area, especially during JJA and SON (Fig. 9). The result is a lower control 

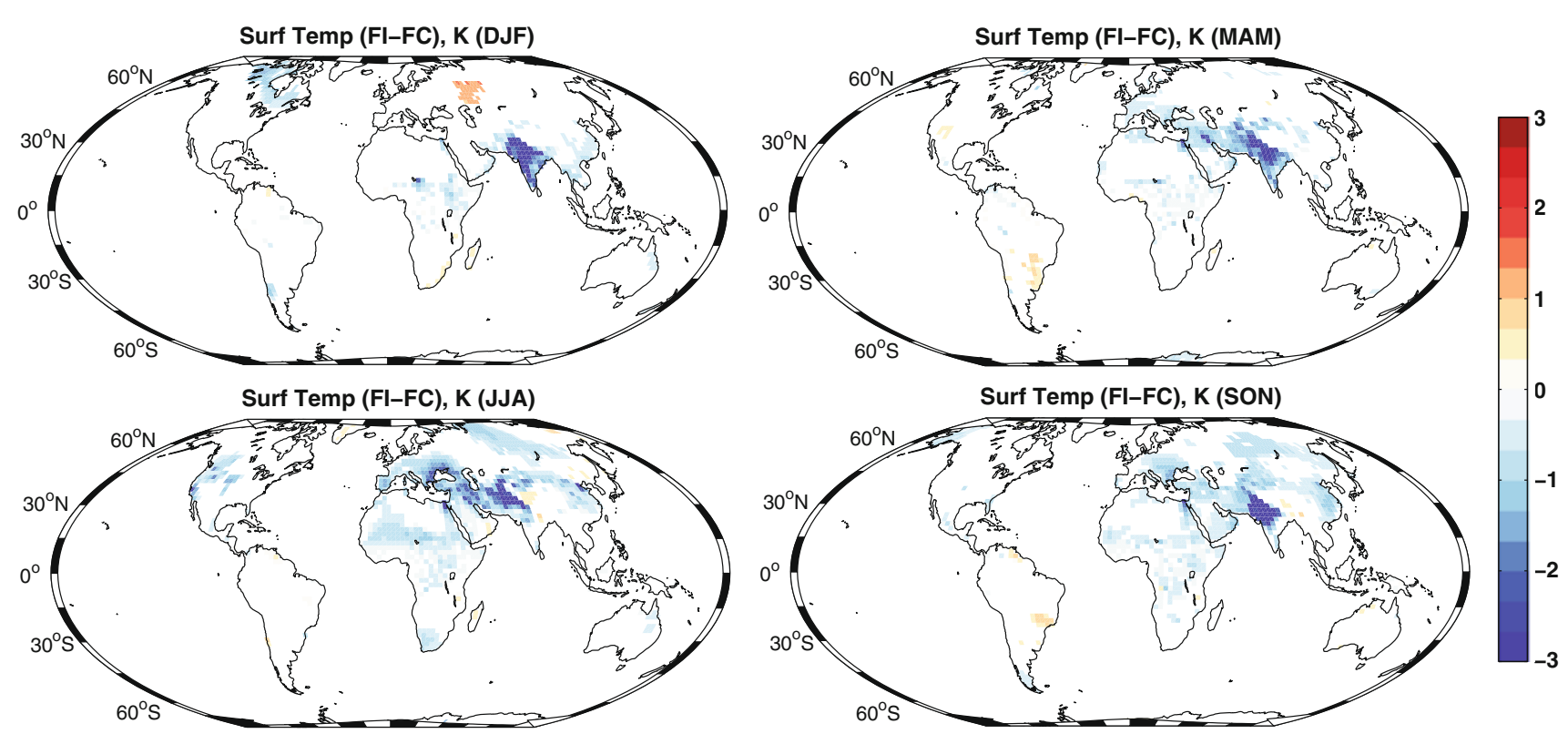

Fig. 10 Differences in seasonal surface air temperature (K) over land areas for the future irrigation comparison (FI-FC)
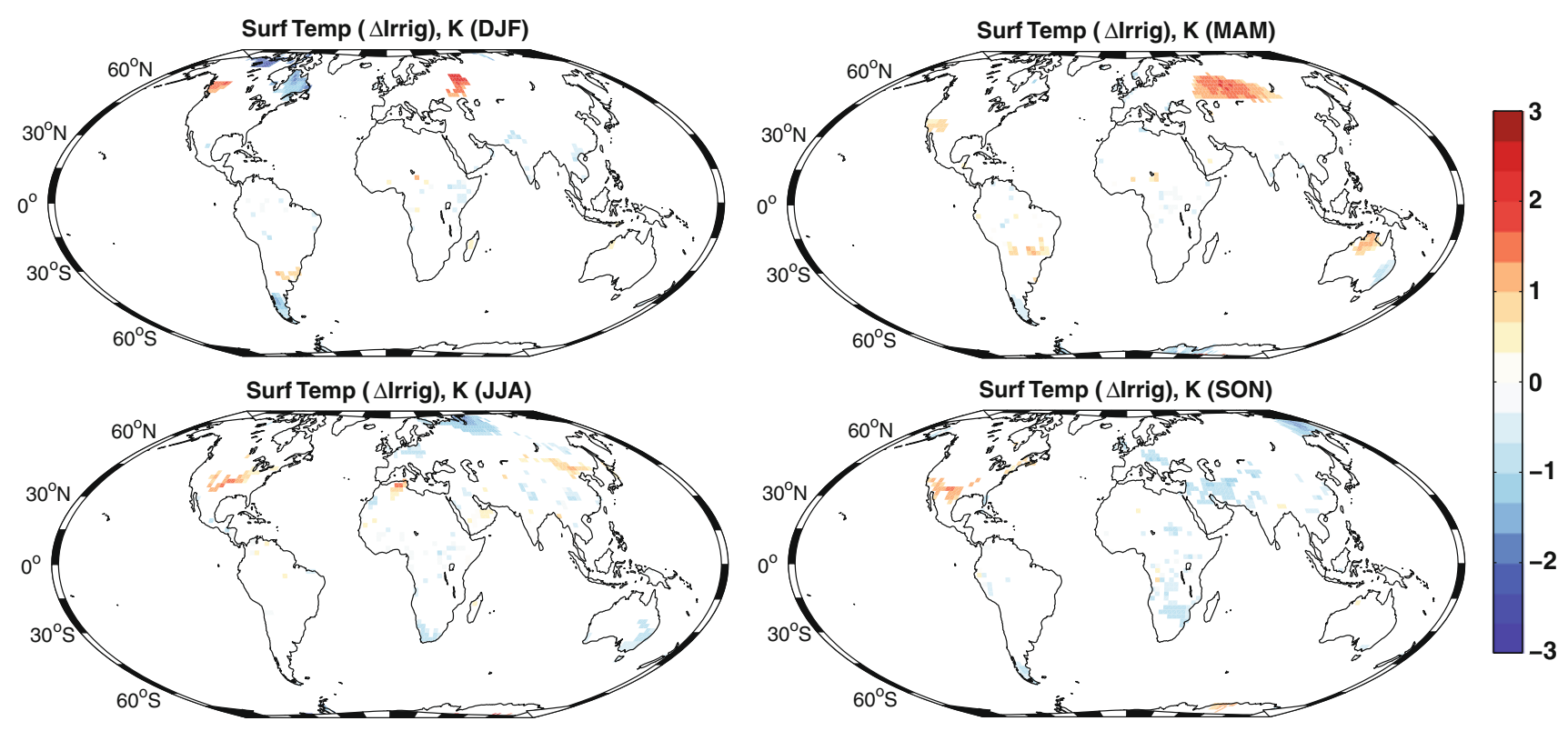

Fig. 11 Difference in irrigation cooling effect (K) between future (FI-FC) and modern (MI-MC) climate scenarios. Red areas indicate where the cooling effect of irrigation is diminished under the future climate scenario; blue areas where the magnitude of irrigation cooling has increased

case (FC) EF and a shift to a more moisture limited background evaporative regime. Any addition of moisture from irrigation will thus have a correspondingly larger impact on latent heat fluxes and the surface energy balance, increasing the cooling effect of irrigation. Irrigation in the future case also amplifies precipitation over China. Combined, these factors lead to a net increase in surface latent heat fluxes and amplification of the irrigation cooling effect (Fig. 13). Averaged over the region, the amplification of the irrigation cooling effect is most apparent during November-December, although some grid cells show enhancement for both the JJA and SON seasons (Fig. 11).

\subsection{Regional changes: Middle East}

Over the Middle East region, the major enhancement to the irrigation cooling effect occurs during October-December (Fig. 14). Increased GHG forcing alone warms the region (Fig. 8), but causes little change in the precipitation 
Fig. 12 Month by month differences (MI-MC and FI-FC) in surface air temperature $(\mathrm{K})$, latent heat fluxes $\left(\mathrm{W} \mathrm{m}^{-2}\right)$, precipitation $\left(\mathrm{mm} \mathrm{day}^{-1}\right)$, and evaporative fraction (unitless) for the North American irrigation region $\left(130^{\circ} \mathrm{W}-85^{\circ} \mathrm{W}\right.$, $30^{\circ} \mathrm{N}-46^{\circ} \mathrm{N}$ ). Note: the axis is flipped in the surface temperature graph, so that the cooling effect (negative temperature anomalies) of the irrigation move in the same direction as the other variables

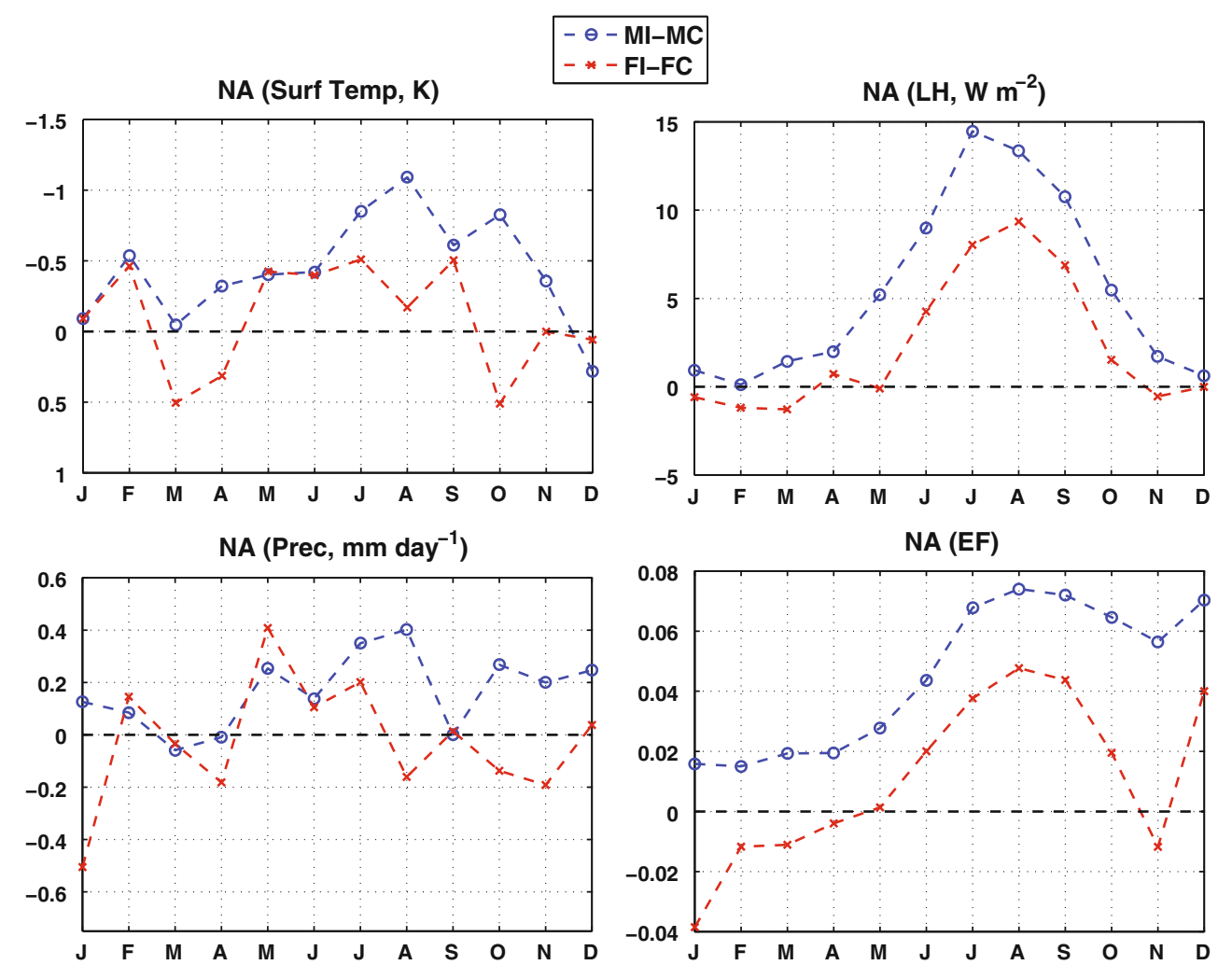

Fig. 13 Month by month differences (MI-MC and FI-FC) in surface air temperature $(\mathrm{K})$, latent heat fluxes $\left(\mathrm{W} \mathrm{m}^{-2}\right)$, precipitation $\left(\mathrm{mm} \mathrm{day}^{-1}\right)$, and evaporative fraction (unitless) for the China irrigation region $\left(98^{\circ} \mathrm{E}-122^{\circ} \mathrm{E}, 22^{\circ} \mathrm{N}-42^{\circ} \mathrm{N}\right)$

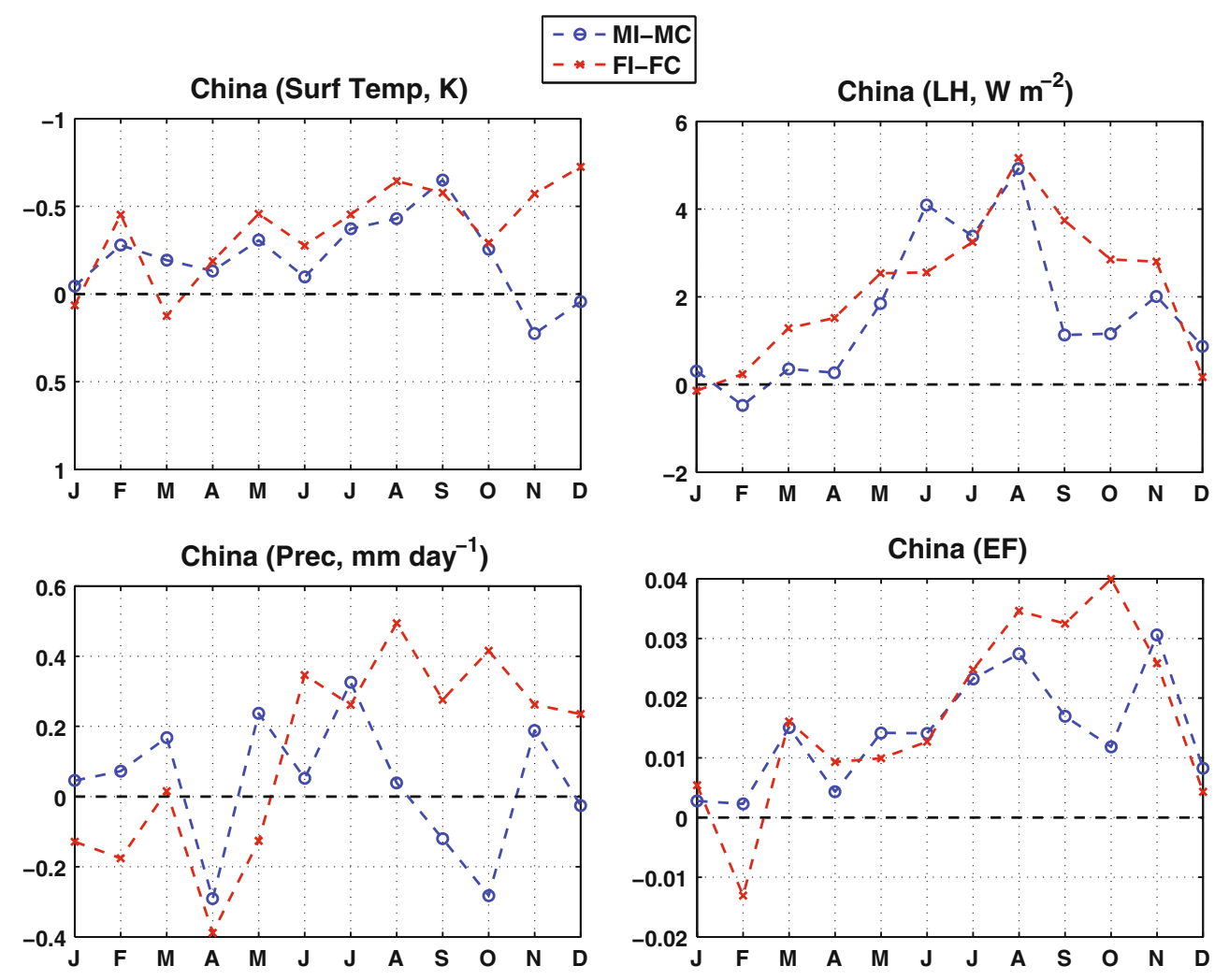

(Fig. 9). In the future, however, irrigation does lead to a larger precipitation enhancement, primarily during October-December, increasing latent heat fluxes and amplifying the irrigation cooling. This result, combined with a weakening of the irrigation-precipitation response over North America, suggests that secondary climate responses to 
Fig. 14 Month by month differences (MI-MC and FI-FC) in surface air temperature $(\mathrm{K})$, latent heat fluxes $\left(\mathrm{W} \mathrm{m}^{-2}\right)$, precipitation $\left(\mathrm{mm} \mathrm{day}^{-1}\right)$, and evaporative fraction (unitless) for the Middle East irrigation region $\left(35^{\circ} \mathrm{E}-67^{\circ} \mathrm{E}, 15^{\circ} \mathrm{N}-\right.$ $\left.48^{\circ} \mathrm{N}\right)$
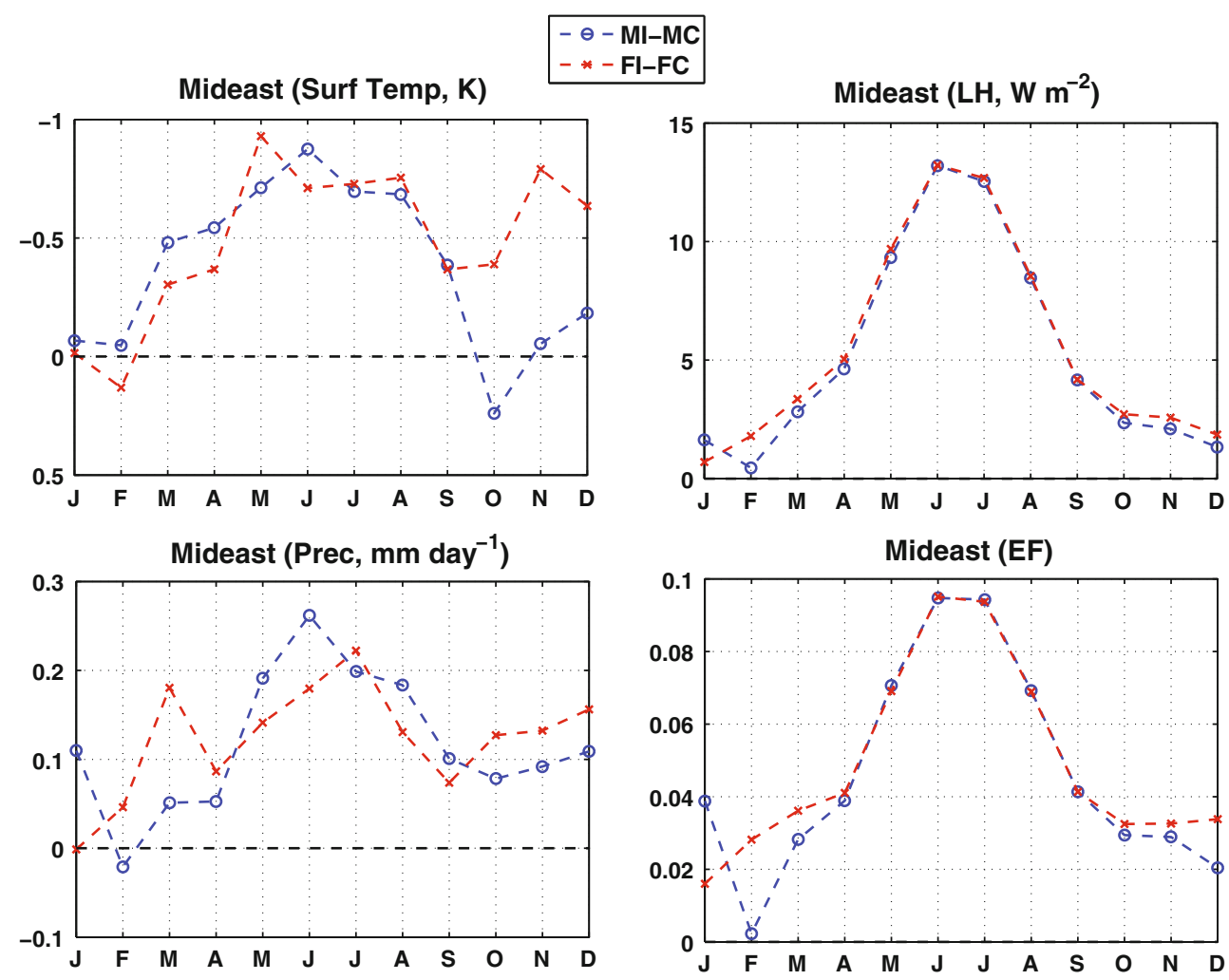

irrigation may be critical for understanding the net total impact of irrigation on surface temperatures.

\subsection{Regional changes: India}

Over India, the impact of irrigation remains largely the same for the two levels of GHG forcing (Fig. 15). Irrigation impacts on surface temperature are strongest during the dry seasons before and after the summer monsoon, when the addition of irrigation can increase LH flux by up to $25-30 \mathrm{~W} \mathrm{~m}^{-2}$. These results suggest that current irrigation rates over India are high enough to meet the evaporative demand under both modern and increased GHG forcing, and that the associated irrigation induced cooling will be neither enhanced or diminished.

\section{Discussion and conclusions}

Anthropogenic land use and land cover changes have been important climate forcing agents in the past, and will remain active components of the climate system into the future. Trends in land use are driven by a variety of complex factors, including population growth, access, government regulation, and economic pressure and opportunities (Geist and Lambin 2002; Lambin et al. 2001). In the case of increasing intensity of land use, such as intensive fertilizer use and irrigation, future trajectories will also depend on a myriad of resource sustainability issues. Maintaining or expanding irrigation rates, for example, will depend on continued access to surface and subsurface water resources and the energy inputs necessary to maintain and operate the infrastructure required to extract, transport, and apply irrigation water.

Assuming we can maintain modern irrigation rates for the foreseeable future, the impact of irrigation on the climate system, especially surface temperature, will depend largely on changes to the state of the background climate from increased GHG concentrations. Here, we have attempted to assess how increased GHG forcing will modulate the direct surface cooling effect of irrigation. Our main conclusions are summarized:

- The direct surface temperature response to irrigation is controlled primarily by the amount of irrigation and the background evaporative regime, with larger cooling anomalies in cases of higher irrigation rates and a more moisture limited background evaporative regime.

- Under increased GHG forcing (SRES A1B scenario), our model experiments suggest that irrigation impacts on near surface air temperature will decrease (North America), increase (China, Middle East), or remain the same (India), depending on how the background climate changes and the intensity of irrigation.

- Over North America, the irrigation impact on surface temperatures is muted due to a dampened irrigation- 
Fig. 15 Month by month differences (MI-MC and FI-FC) in surface air temperature $(\mathrm{K})$, latent heat fluxes $\left(\mathrm{W} \mathrm{m}^{-2}\right)$, precipitation $\left(\mathrm{mm} \mathrm{day}^{-1}\right)$, and evaporative fraction (unitless) for the India irrigation region $\left(68^{\circ} \mathrm{E}-88^{\circ} \mathrm{E}, 8^{\circ} \mathrm{N}-36^{\circ} \mathrm{N}\right)$
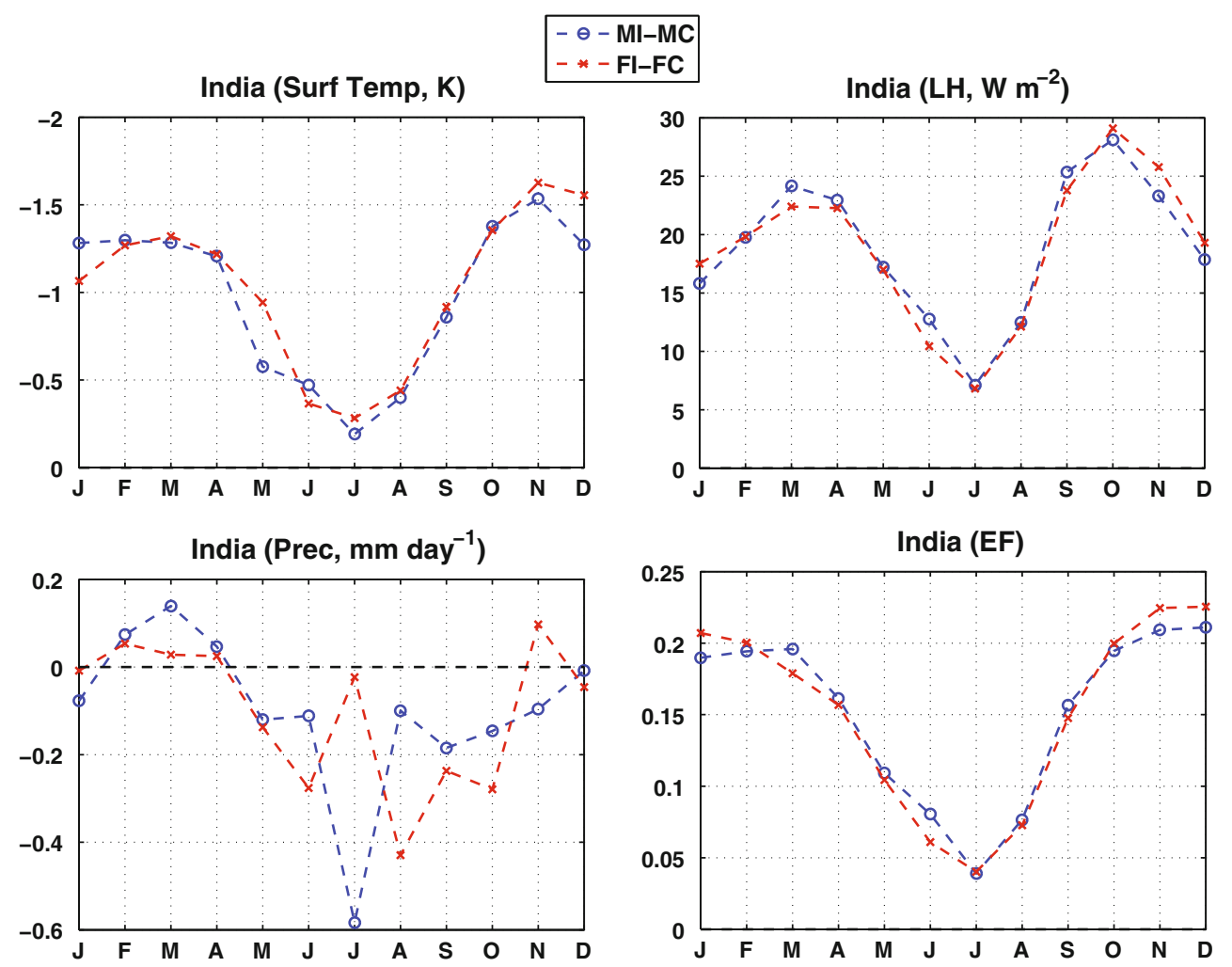

precipitation response which, under modern GHG forcing, acts to double total latent heat fluxes. Conversely, amplified irrigation cooling in the Middle East and China is due, at least partially, to enhanced precipitation from irrigation under increased GHG concentrations. This highlights the potential importance of irrigation impacts on other components of the climate system for understanding the full temperature response.

Our study takes a different approach from previous investigations into the effect of GHG forcing and irrigation on surface temperatures (Bonfils and Lobell 2007; Lobell et al. 2008). Those studies focused primarily on the transient response, and concluded that the rates of irrigation expansion and increasing GHG concentrations were the most important considerations for understanding irrigation masking of global warming. Our study expands on this foundation by considering the equilibrium response of the climate system because irrigation impacts will also depend on how the background climate state changes with increased GHG forcing. Here we have found that, at least within this modeling framework, we may expect spatially variable changes in the strength of the irrigation impact, depending on the regional responses to increased GHG.

Over several regions we also show the importance of indirect effects on the magnitude of the irrigation cooling. Over North America, for example, increased precipitation from irrigation essentially doubles the latent heat flux anomaly and subsequent cooling under modern GHG forcing; this precipitation enhancement largely disappears in the increased GHG scenario. The robustness and importance of these secondary irrigation-climate impacts, however, are still poorly understood. The direct impact of irrigation on surface temperature is well constrained and is controlled primarily by simple surface energy balance considerations. Precipitation, however, depends not only on evapotranspiration, but also on boundary layer dynamics, atmospheric stability, moisture advection, large scale circulation, etc. The magnitude (and even direction) of precipitation responses to irrigation are therefore likely to be much more sensitive to the background climate and model parameterizations than temperature responses. There is observational and modeling support for positive soil moisture-precipitation coupling (for a comprehensive review, see Seneviratne et al. 2010), despite wide variance across models in the strength of these interactions (e.g. Koster et al. 2004). More importantly for our study, there is evidence for irrigation enhancement of precipitation over North America (Barnston and Schickedanz 1984; DeAngelis et al. 2010). Despite the uncertainties, the secondary effects of irrigation on precipitation and other atmospheric variables may be important for understanding how irrigation impacts on surface temperatures will change into the future.

Finally, we note that the implicit assumption in our model scenarios is that current irrigation rates will be 
maintained into the future. There is already evidence, however, that irrigation expansion rates have slowed down (Bonfils and Lobell 2007) and that the future availability of water resources for irrigation is uncertain (Shen et al. 2008). In regions where groundwater makes up a large component of irrigation water withdrawal, water which is non-renewable on timescales relevant to societies (i.e. 'fossil water'), extraction is becoming harder and these resources are being depleted rapidly (Rodell et al. 2009; Sophocleous 2010). In other areas where surface reservoirs are the main source, these resources may be highly sensitive to future climate change. One stark example is western North America, where recent droughts have led to sharp declines in available water resources, droughts that may be a harbinger of increased desiccation in the future (Barnett et al. 2008; Seager et al. 2007). The sustainability of irrigation, and irrigation impacts on climate, therefore also crucially depends on the ability of societies to sustain or increase modern irrigation rates in the face of possibly depleting water resources due to unsustainable extraction practices or potentially detrimental climate changes.

Acknowledgments The authors wish to thank the anonymous reviewers who greatly improved the quality of this manuscript. NY Krakauer acknowledges the support of the National Oceanic and Atmospheric Administration (NOAA), under Grant Number NA06OAR4810162. MJ Puma gratefully acknowledges funding for Interdisciplinary Global Change Research under NASA Cooperative Agreement NNX08AJ75A supported by the NASA Climate and Earth Observing Program. Lamont contribution number \#7407.

\section{References}

Adegoke J, Pielke Sr R, Eastman J, Mahmood R, Hubbard K (2003) Impact of irrigation on midsummer surface fluxes and temperature under dry synoptic conditions: a regional atmospheric model study of the US High Plains. Mon Wea Rev 131(3):556564

Ball J, Woodrow I, Berry J (1987) A model predicting stomatal conductance and its application to the control of photosynthesis under different environmental conditions. In: Biggins I (ed) Progress in photosynthesis. Martinus Nijhoff Publishers, Dordrecht, pp 221-224

Barnett T, Pierce D, Hidalgo H, Bonfils C, Santer B, Das T, Bala G, Wood A, Nozawa T, Mirin A et al (2008) Human-induced changes in the hydrology of the western United States. Science 319(5866):1080-1083

Barnston A, Schickedanz P (1984) The effect of irrigation on warm season precipitation in the southern Great Plains. J Clim Applied Meteorol 23(6):865-888

Bonfils C, Lobell D (2007) Empirical evidence for a recent slowdown in irrigation-induced cooling. Proc Nat Acad Sci 104(34): 13582-13587

Bonfils C, Duffy P, Santer B, Wigley T, Lobell D, Phillips T, Doutriaux C (2008) Identification of external influences on temperatures in California. Clim Change 87:43-55

Boucher O, Myhre G, Myhre A (2004) Direct human influence of irrigation on atmospheric water vapour and climate. Clim Dyn 22(6):597-603
DeAngelis A, Dominguez F, Fan Y, Robock A, Kustu M, Robinson D (2010) Evidence of enhanced precipitation due to irrigation over the Great Plains of the United States. J Geophys Res Atmos 115:1-14. doi:10.1029/2010JD013892

FAO (2002) Crops and drops: making the best use of water for agriculture. Tech. rep., Food and Agriculture Organization of the United Nations, Rome

Farquhar G, Caemmerer S, Berry J (1980) A biochemical model of photosynthetic $\mathrm{CO}_{2}$ assimilation in leaves of $\mathrm{C} 3$ species. Planta 149(1):78-90

Feddema J, Oleson K, Bonan G, Mearns L, Buja L, Meehl G, Washington W (2005) The importance of land-cover change in simulating future climates. Science 310(5754):1674-1678

Foley J, DeFries R, Asner G, Barford C, Bonan G, Carpenter S, Chapin F, Coe M, Daily G, Gibbs H et al (2005) Global consequences of land use. Science 309(5734):570-574

Geist H, Lambin E (2002) Proximate causes and underlying driving forces of tropical deforestation. BioScience 52(2):143-150

Hansen J, Sato M, Ruedy R, Kharecha P, Lacis A, Miller R, Nazarenko L, Lo K, Schmidt G, Russell G, et al. (2007) Climate simulations for 1880-2003 with GISS modelE. Clim Dyn 29(7):661-696

Koster R, Dirmeyer P, Guo Z, Bonan G, Chan E, Cox P, Gordon C, Kanae S, Kowalczyk E, Lawrence D et al (2004) Regions of strong coupling between soil moisture and precipitation. Science 305(5687):1138-1141

Kueppers L, Snyder M, Sloan L (2007) Irrigation cooling effect: Regional climate forcing by land-use change. Geophys Res Lett 34:1-5. doi:10.1029/2006GL028679

Lambin E, Turner B, Geist H, Agbola S, Angelsen A, Bruce J, Coomes O, Dirzo R, Fischer G, Folke C, et al. (2001) The causes of land-use and land-cover change: moving beyond the myths. Glob Environ Change 11(4):261-269

Lobell D, Bonfils C (2008) The effect of irrigation on regional temperatures: aspatial and temporal analysis of trends in California, 1934-2002. J Clim 21(10):2063-2071

Lobell D, Bala G, Bonfils C, Duffy P (2006a) Potential bias of model projected greenhouse warming in irrigated regions. Geophys Res Lett 33:1-4. doi:10.1029/2006GL026770

Lobell D, Bala G, Duffy P (2006b) Biogeophysical impacts of cropland management changes on climate. Geophys Res Lett 33(6):L06, 708

Lobell D, Bonfils C, Faurès J (2008) The role of irrigation expansion in past and future temperature trends. Earth Interact 12:1-11. doi:10.1175/2007EI241.1

Matthews E (1983) Global vegetation and land use: new highresolution data bases for climate studies. J Clim Appl Meteorol 22(3):474-487

Matthews E (1984) Prescription of land-surface boundary conditions in GISS GCM II: a simple method based on fine-resolution data bases. Tech. rep., NASA

Nakicenovic N, Alcamo J, Davis G, de Vries B, Fenhann J, Gaffin S, Gregory K, Grubler A, Jung T, Kram T et al (2000) Special report on emissions scenarios: a special report of working group III of the intergovernmental panel on climate change. Cambridge

Oleson K, Bonan G, Feddema J, Vertenstein M, Grimmond C (2008) An urban parameterization for a global climate model. Part I: Formulation and evaluation for two cities. J Appl Meteorol 47(4):1038-1060

Oleson K, Bonan G, Feddema J, Boulder C, Oleson K (2010) Effects of white roofs on urban temperature in a global climate model. Geophys Res Lett 37:1-7. doi:10.1029/2009GL042194

Pielke Sr R, Marland G, Betts R, Chase T, Eastman J, Niles J, Niyogi D, Running S (2002) The influence of land-use change and landscape dynamics on the climate system-relevance to climate change policy beyond the radioactive effect of greenhouse gases. Philis Trans Royal Soc Lond A 360:1705-1719 
Pongratz J, Reick C, Raddatz T, Claussen M (2010) Biogeophysical versus biogeochemical climate response to historical anthropogenic land cover change. Geophys Res Lett 37:1-5. doi:10.1029/ 2010GL043010

Puma M, Cook B (2010) Effects of irrigation on global climate during the 20th century. J Geophys Res 115:1-15. doi:10.1029/2010 JD014122

Rodell M, Velicogna I, Famiglietti J (2009) Satellite-based estimates of groundwater depletion in India. Nature 460(7258):999-1002

Rosenzweig C, Abramopoulos F (1997) Land-surface model development for the GISS GCM. J Clim 10:2040-2054

Sacks W, Cook B, Buenning N, Levis S, Helkowski J (2009) Effects of global irrigation on the near-surface climate. Clim Dyn 33(2):159-175

Schmidt G, Ruedy R, Hansen J, Aleinov I, Bell N, Bauer M, Bauer S, Cairns B, Canuto V, Cheng Y, et al. (2006) Present-day atmospheric simulations using GISS ModelE: Comparison to in situ, satellite, and reanalysis data. J Clim 19(2):153-192

Seager R, Ting M, Held I, Kushnir Y, Lu J, Vecchi G, Huang H, Harnik N, Leetmaa A, Lau N et al (2007) Model projections of an imminent transition to a more arid climate in southwestern
North America. Science 316:1181-1184. doi:10.1126/science. 1139601

Seneviratne S, Corti T, Davin E, Hirschi M, Jaeger E, Lehner I, Orlowsky B, Teuling A (2010) Investigating soil moistureclimate interactions in a changing climate: A review. Earth Sci Rev 99:125-161

Shen Y, Oki T, Utsumi N, Kanae S, Hanasaki N (2008) Projection of future world water resources under SRES scenarios: water withdrawal. Hydrol Sci J 53:31-52. doi:10.1016/j.gloenvcha. 2003.10.006

Solomon S, Qin D, Manning M, Chen Z, Marquis M, Averyt K, Tignor M, Miller H (2007) Climate change 2007: the physical science basis. Cambridge University Press, Cambridge, New York

Sophocleous M (2010) Review: groundwater management practices, challenges, and innovations in the High Plains aquifer, USAlessons and recommended actions. Hydrogeol J 18(3):559-575

Wisser D, Fekete B, Vorosmarty C, Schumann A (2010) Reconstructing 20th century global hydrography: a contribution to the lobal Terrestrial Network-Hydrology (GTN-H). Hydrol Earth Syst Sci 14:1-24 